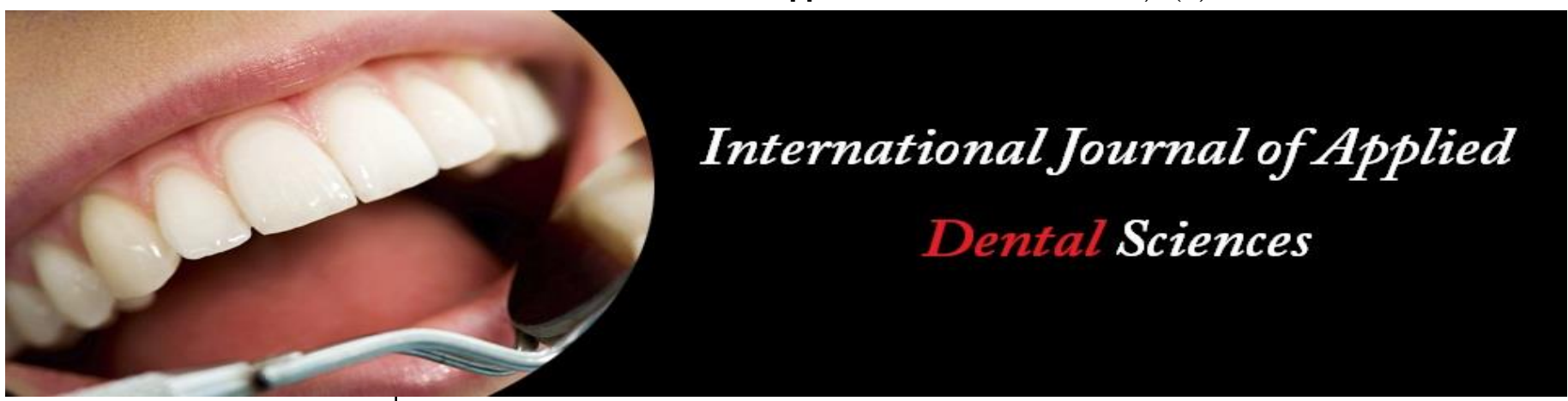

ISSN Print: 2394-7489

ISSN Online: 2394-7497

IJADS 2021; 7(3): 160-162

(C) 2021 IJADS

www.oraljournal.com

Received: 10-05-2021

Accepted: 12-06-2021

Dr. Nandini Jain

BDS, Post Graduate Trainee,

ITS Dental College, Muradnagar,

Uttar Pradesh, India

Dr. Sheetal Bisht

BDS, Post Graduate Trainee,

ITS Dental College, Muradnagar,

Uttar Pradesh, India

Dr. Sapna Rani

MDS, Reader, ITS Dental

College, Muradnagar,

Uttar Pradesh, India

Dr. Kamal Vashisht

BDS, Post Graduate Trainee,

ITS Dental College, Muradnagar,

Uttar Pradesh, India

Dr. Shuja Mohammed Khan BDS, Post Graduate Trainee,

ITS Dental College, Muradnagar,

Uttar Pradesh, India
Corresponding Author:

Dr. Nandini Jain

BDS, Post Graduate Trainee,

ITS Dental College, Muradnagar,

Uttar Pradesh, India

\section{A novel and innovative technique for fabrication of customized detachable cheek plumper: A clinical case report}

\author{
Dr. Nandini Jain, Dr. Sheetal Bisht, Dr. Sapna Rani, Dr. Kamal Vashisht \\ and Dr. Shuja Mohammed Khan
}

DOI: https://doi.org/10.22271/oral.2021.v7.i3c.1294

\section{Abstract}

Prosthetic rehabilitation of a completely edentulous patient no longer confines to only replacement of missing teeth. Patients are increasingly demanding improvement in esthetics at the end of treatment. Aging leads to a high impact on external facial esthetics resulting in slumped cheek leading to undesirable facial esthetics. Cheek plumper is a commonly used prosthesis to enhance the support of sunken cheeks providing better esthetics. This clinical report describes a novel technique to fabricate detachable cheek plumber to improve support for sunken cheeks retained with a ball bearing and a new commercially available material.

Keywords: cheek plumper, novel technique, facial esthetics, ball bearing

\section{Introduction}

Facial aesthetics are of an utmost importance in person's professional and social life ${ }^{[1]}$. With advanced age, rapid resorption of bone takes place after loss of teeth. Patients who have lost molars may appear as sunken or "hollow" cheeks ${ }^{[2]}$. Individuals with hollow cheeks require additional support to the fascia in addition to conventional denture ${ }^{[3]}$.

The requirement of extra bulk was fulfilled by an appliance known as cheek lifting appliance or cheek plumper. These can be of two types: Conventional / Undetachable /Fixed cheek plumper and Modified /Detachable /Removable cheek plumper.

Undetachable cheek plumper is single-unit prosthesis but has disadvantages: Extra bulk, increased weight and also external contour of plumper is not contoured to function in harmony with musculature, leading to frequent dislodgement. These prostheses cannot be used in patients with limited mouth opening ${ }^{[4]}$.

These flaws can be overcome by using a detachable plumper. Many attachments have been used such as magnets, ball end clasps and springs. Their merits include: easy retrieval, easy to clean, economical, improved aesthetics ${ }^{[5]}$.

This clinical report illustrates a simple, cost-effective, innovative and efficient technique for fabrication of detachable cheek plumper prosthesis in a completely edentulous patient with hollow cheeks using ball bearing as male component and new commercially available material as female component.

\section{Case Report}

A 60-year-old male patient reported to Department of Prosthodontics, with chief complaint of difficulty in chewing due to missing teeth and non-pleasing appearance due to slumping cheeks. Extra-oral examination revealed wrinkled skin and hollow sunken cheeks. On intraoral examination, patient had completely edentulous arches.

As patient was seeking improvement in his facial appearance, a treatment plan was formulated for maxillary complete denture with detachable cheek plumper after patient's consent.

Preliminary and definitive impressions were made in conventional manner. Jaw relation was recorded along with face bow transfer onto the semi-adjustable articulator. 
On evaluation, posterior cross bite was found; teeth arrangement was done and evaluated as per the phonetics and esthetics.

\section{Recording cheek plumper}

Modeling wax block was adapted on the corresponding region of maxillary dummy denture. Hollowness of cheeks was evaluated from the frontal and occlusal view. While the wax up was done, it was extended till the occlusal surface and any interference was removed during eccentric movement. Once found satisfactory, tissue conditioner was applied over the trimmed wax up part of cheek plumper. The patient was asked to activate all muscles by performing functions like movement of the cheek, licking, smiling, sucking, pursing of lips and whistling. Following the complete polymerization of tissue conditioner, its extension onto the peripheral seal area was reduced by $2 \mathrm{~mm}$ to keep it away from the denture borders (Fig 1). An index of the molded tissue conditioner was made using elastomeric impression material (Affinis, Coltene Whaledent).

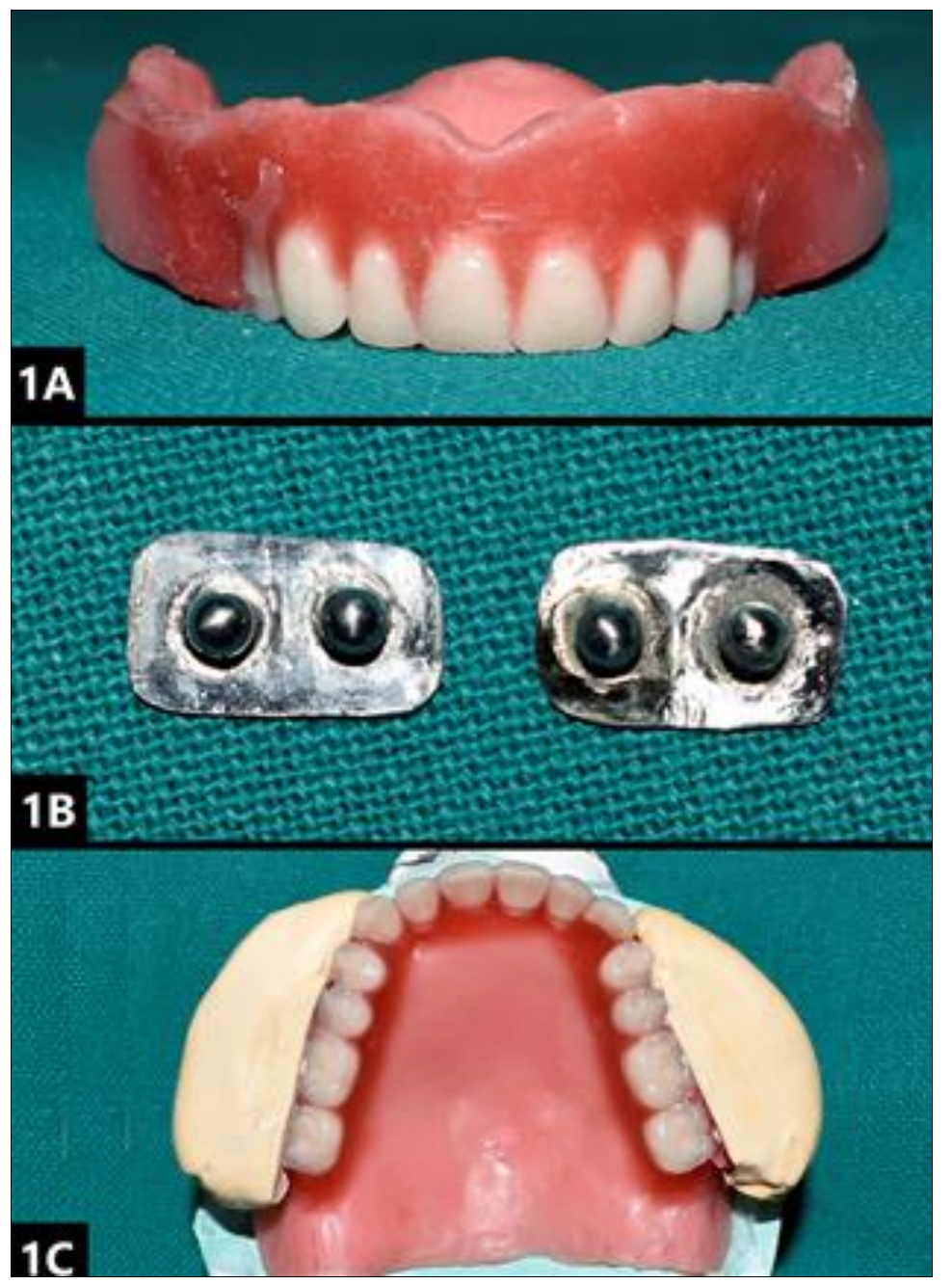

Fig 1: Molding of cheek plumper with soft tissue conditioner (1A), Customized retentive component (1B), Wax pattern fabrication of cheek plumper with putty index (1C)

\section{Customization of attachments for detachable cheek plumper}

Attachment consisted of a flat rectangular thin base and two ball bearings of $3 \mathrm{~mm}$ diameter soldered onto it. The width of rectangular base was kept slightly short of the width of the plumper prosthesis. This prefabricated attachment was waxed in the complete denture in place of the plumper prosthesis.

\section{Wax pattern fabrication}

The retentive attachments and the buccal flange were duplicated using irreversible hydrocolloid material and poured in type II gypsum product. Molten baseplate wax was poured into the putty index fabricated on molded tissue conditioner surface of cheek plumper and was oriented onto the duplicated cast after applying a thin layer of petroleum jelly. The wax pattern thus obtained was evaluated for appropriate thickness and fit on the cast (Fig 2A).

\section{Processing of cheek plumper}

Processing of cheek plumper and maxillary denture with the attachments placed on the buccal surface of denture was processed individually in heat cure resin (Travelon, Dentsply) (Fig 2B). The processed plumper on both sides was tried in the patient's mouth and recess was made with respect to ball bearing in detached cheek plumper. A new commercially available material, Retention. Sil (Bredent, Germany) was placed in the plumper part as a female component, corresponding to the attachments giving a snap fit (Fig 2C). This allowed close approximation of the plumper with the denture and also facilitated easy removal from it.

Complete denture with detachable cheek plumper was inserted in the patient's mouth. Patient's face appeared esthetically pleasing and evident difference was noticeable (Fig 3). The patient was given instructions regarding the attachment and detachment of the cheek plumper and was asked to present for regular follow up. 


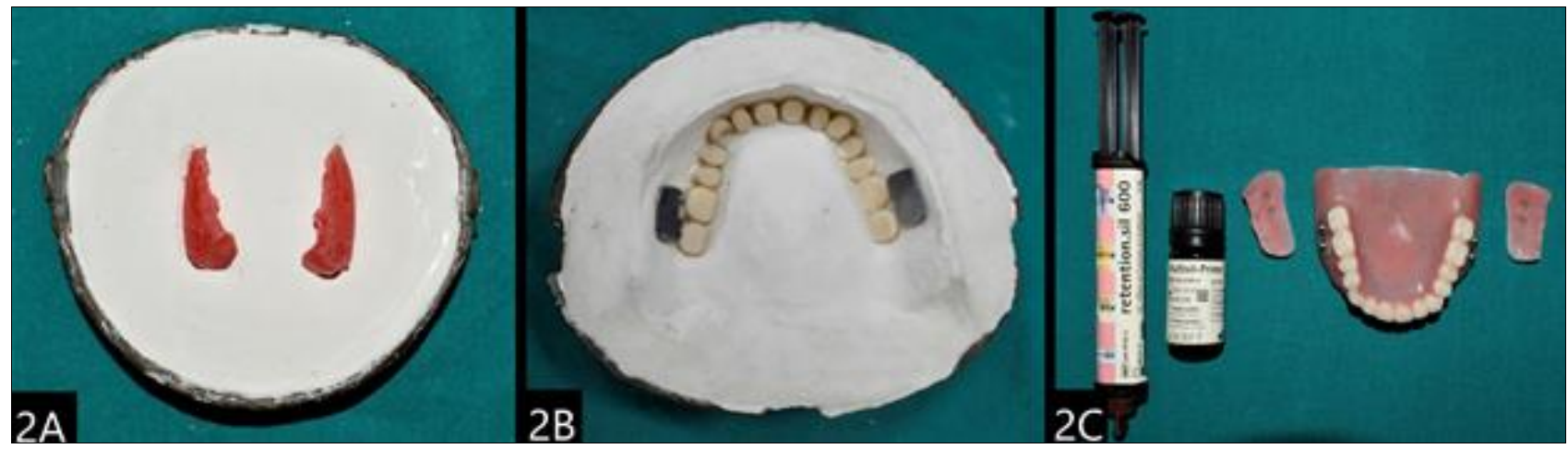

Fig 2: Fabrication of cheek plumper (2A), Flasking of denture with customized component (2B), Pickup of male component of cheek plumper with retention. Sil material (2C)

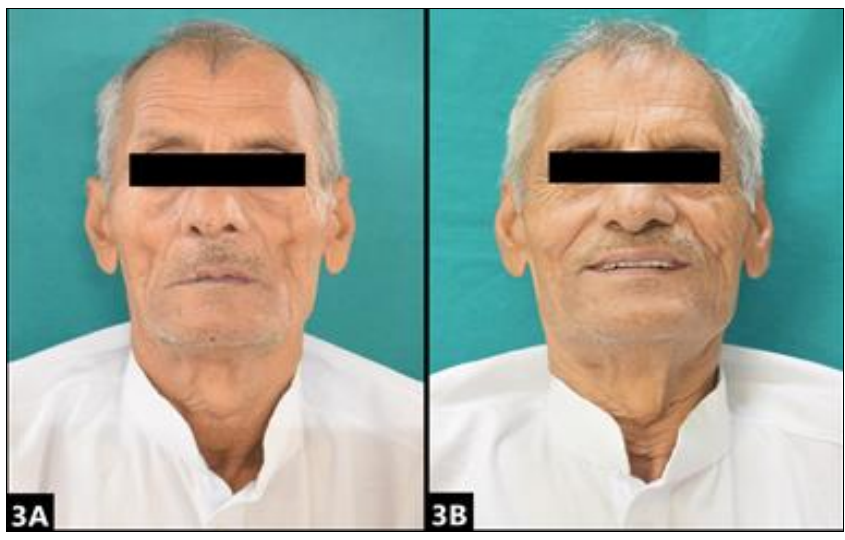

Fig 3: Pre-operative frontal view of patient (3A), Post-operative frontal view of patient (3B)

\section{Discussion}

Conventional cheek plumper presents various limitations due to their increased size and weight which leads to dislodgement of prosthesis ${ }^{[6]}$. Previous studies have discussed the use of press stud fasteners and magnets ${ }^{[6-9]}$. Few authors have used stud attachments, wire-retained cheek plumper, and orthodontic elastic modules ${ }^{[10]}$. Clinician can choose the appropriate attachment as per patient's dexterity and need.

In the case report, due to limited inter-commissural width, treatment option of detachable cheek plumper was chosen. Customization of the attachment was done with the help of ball bearings onto a metal plate which was very economical and served as stud male component. For female housing, a new commercially available material was used as the retention documented by the material is sufficient for over denture.

Cheek plumper was extended till the occlusal surface of the opposing denture and any interference during lateral excursions was eliminated. Since the patient had posterior cross bite, this arrangement aided in increasing the masticatory efficiency of the patient augmented with facial esthetics.

However, cheek plumper has a few setbacks, such as the accumulation of food, patient discomfort, requirement of manual dexterity of patients to ensure accurate attachment. With regard to present case report, since a new material was used for retention, so long term follow up is required.

\section{Conclusion}

A new prosthetic treatment with the use of a new available material was used to retain cheek plumper in complete denture. This was simple and cost-effective treatment, aiding in the improvement of facial appearance in a patient with sunken cheeks. The customized attachments retained cheek plumper prosthesis successfully, restored the contour of cheek ultimately improving esthetics and psychological well-being of the patient.

\section{References}

1. Tautin S. Denture esthetics is more than tooth selection. J Prosthet Dent 1978;40(2):127-30.

2. Jamieson C. Geriatrics and the denture patient. J Prosthet Dent 1958;8:8-13.

3. Virdiya NM, Palaskar JN, Wankhade J, Joshi N. Detachable cheek plumpers with different attachments for improving esthetics in a conventional complete denture: A clinical report. J Prosthet Dent 2017;117(5):592-6.

4. Aras MA. Customised Attachments Retained Cheek Plumper Prosthesis: A Case Report Customised Attachments Retained Cheek Plumper Prosthesis: A Case Report. J indian Prosthodont Soc 2012;12(3):198200.

5. Kumar B, Sandhu PK, Bhatia S, Kumar AN. An Innovative Solution To Slumped Cheeks: Spring Retained Cheek Plumper - A Case Report. J Dent Med Sci 2017;16(1):55-7.

6. Punia V, Mishra R, Khandelwal M, Verma N, Handa M. Magnet retained detachable cheek plumper: innovation personified-A case report. Int J Prosthet Dent 2013;4:1620.

7. Deogade SC. Magnet retained cheek plumper in complete denture esthetics: A case report. J Dent 2014;11:100-5.

8. Riley MA, Walmsley AD, Harris IR. Magnets in prosthetic dentistry. J Prosthet Dent 2001;86:137-42.

9. Keni NN, Aras MA, Chitre V. Customised attachments retained cheek plumper prosthesis: a case report. J Indian Prosthodont Soc 2012;12:198-200.

10. Nandita Keni N, Meena Aras A. Vidya Chitre. Customised Attachments Retained Cheek Plumper Prosthesis: A Case Report. J Indian Prosthodont Soc 2012;12(3):198-200. 